\title{
The Basketball Shoe Brand Preference of the Young Basketball Enthusiasts in Hong Kong 本港年青籃球愛好者對籃球鞋品牌的喜好
}

\author{
Lobo LOUIE \\ Department of Physical Education, \\ Hong Kong Baptist University, HONG KONG \\ 雷雄德 \\ 香港浸會大學體育學系
}

\begin{abstract}
The study attempts to investigate the choice preference of basketball shoe brands as perceived by the young basketball players in Hong Kong. A survey questionnaire was designed with content validity being established. The data for this study were collected from 240 young basketball enthusiasts in Hong Kong. Data were treated utilizing descriptive statistics mainly in terms of frequency counts and percentages. Chi-square statistic was used to determine the gender differences in various variables. Nike is the most dominant basketball shoe brand as indicated by the respondents. Male subjects chose the basketball shoe products because of the 'comfortableness' and 'price', whereas shoe 'style' is the females' first choice. Kobe Bryant, Michael Jordan, and Lebron James were identified as the top three most popular NBA players who are endorsers to basketball shoe brands. The use of NBA to promote basketball shoe branding in Hong Kong appears to have further room for development. The present finding provides some insight and understanding about the basketball shoe products and market in Hong Kong.
\end{abstract}

Keywords - basketball shoe, NBA, brand preference

\section{摘 要}

本研究旨在探討本港年青籃球愛好者對籃球鞋品牌的喜好, 研究以問卷調查方式進行, 共收集了 240 名年青籃球愛好者的意 見並進行統計分析。結果顯示：Nike是最受歡迎的品牌；「舒適」和「價錢」是男性受訪者喜歡選購籃球鞋的原因；而女性則喜 愛籃球鞋的款式。高比拜仁、米高佐敦及勒邦占士的贊助品牌是最受年青籃球愛好者所喜歡的。

關鍵詞： 籃球鞋、NBA、品牌

\section{Introduction}

Basketball is one of the fastest-growing sports in the world, especially in China. China has a very broad market for basketball and it is one of the most popular sports in China since Yao Ming's NBA performances are featured frequently in the Chinese media. In an article entitled 'NBA reaches out to ever-growing basketball fan base in China' written by Todd (2006), he indicated that China is the NBA's second largest basketball market and a country with vast room for expansion. Today, there are an estimated 300 million basketball fans in China. It creates a great market for sport products. Sports product can be a good, a service, or any combination of 
the two that is designed to provide benefits to a sports spectator, participant, or sponsor (Shank, 2009). Basketball shoes and jerseys are the common sport products welcome by young basketball fans.

Hong Kong is one of the major cities in southeast coast of China, with a population of about 6.99 million. Sport business in Hong Kong is responsible for employing some 80,000 employees according to a recent study commissioned by the Hong Kong Sports Development Board (2003). This study also revealed that the total economic impact of sport is estimated at $2.5 \%$ and $2.1 \%$ of all employment and GDP value-added in Hong Kong respectively, and is responsible for $2.2 \%$ or some $\$ 51$ billion in gross output. Sport business activities include marketing, design, arranging production of quality sporting goods and equipment in mainland China for the global market. The study further concluded that younger age groups have higher participation rates and have developed stronger habits of participation which are likely to endure. Basketball gains the highest popularity among all youth sports in Hong Kong, is particular enjoyed by the school children (HKSDB, 2001). Understanding the shopping behavioral patterns and sporting product brand preference of the young basketball enthusiasts will give a hand for better promotion of the sports products in the market.

\section{Economic Impact of Sport in Hong Kong}

The Hong Kong Special Administrative Region of the China was established on July 1, 1997 and follows a capitalist system. In 2007, GDP at current market prices amounted to $\$ 1.616 .2$ billion, while per capita GDP has reached \$233,358 (Hong Kong the fact, 2008). According to the only data from the Hong Kong Sports Development Board (2002), the economic benefits created by the sport market in Hong Kong can be assessed with reference to three primary variables: (a) employment, (b) value added (sales less purchase of raw materials and other input), and (c) gross output (gross sales or similar to turnover). The sport market in Hong Kong can be characterized into two areas. The first area is associated with the production, marketing, trade and sale of sporting goods, equipment and clothing. The second area relates to sports participation, provision of facilities and relevant services. In 2000, the sports clothing and footwear production in Hong Kong accounted for a total of 18,094million HK dollars. The retailing of sports goods accounted for 2,414million HK dollars (1 US\$ = 7.8
HK\$). Although sport footwear production and retailing occupies relative large amount of sport market in Hong Kong, however, there is few local research data on the sport products regarding the choice of sport brands or reasons for choosing the sport products.

\section{Literature Review}

Literatures on the concepts of sports products, such as sport product branding and athlete endorsements, will be reviewed in order to provide a better view for our readers. As stated by Fullerton (2007), sports marketing environment encompasses two distinctly different domains, including the demand for spectator sports and selling a variety of sports-related products through an application of sports platform. Traditional marketing strategies represent a lower level of integration in that marketers simply implement strategies with a sport overlay. However, an effective strategy is based upon the recognition that different groups of customers must be approached with initiatives designed specifically for them. For example, Achenreiner and John (2003) found that children learn to relate to brand names at an early age. Children are able to recognize brand names in stores, develop preferences for some brands over others, and request branded items by name. They also found that Nike was the most preferred brand of athletic shoe and Kmart selected as the nonpreferred athletic shoe brand.

Brand name is regarded as an essential part of the brand and the foundation for marketing communication efforts. Brand name not only helps identify the product, but also acquires a set of symbols and meanings embodied by the product (Kohli et al., 2005). Slogans are also a key element of a brand's identity, and contribute to a brand's equity (Kohli et al., 2007). For example, "Just Do it" for Nike, and "Impossible is Nothing" for Adidas are the common slogans seen in sports arena. When a slogan is in a unique position, it can act as a bridge between a brand's legacy and its evolving image. Slogans can also be related to brand awareness, such as memorability, recognition and recall.

Sports have very strong images with many perceived characteristics. The use of athletes as celebrity endorsements is a common strategy in sports market. Great athletes in today's society are expected to engender strong values and morals that conform to societal and cultural norms (Jones \& Schumann, 2002). Fullerton (2007) 
mentioned that the selection of athlete for endorsements is guided by a review of factors such as what the athlete has achieved, how much the consumer can believe what the athlete says, and how easily recognized the athlete is. NBA player LeBron James is a successful example. However, recent studies indicated that there may be some possible negative consequences of using celebrity endorsement (e.g. Bailey, 2007: Louie \& Obermiller, 2002).

Today, athletic shoes are an integral part of almost everyone's wardrobe. For participants, there are designs that are deemed appropriate for specific sport. No longer are the athletic shoes combined into the generic category of sport shoes. The participant market has changed significantly since the advent of Nike's Air Jordon shoes in 1980s (Fullerton \& Merz, 2008). Even street basketball players are wearing good quality basketball shoes. In Japan, a survey was conducted to investigate what the 'good' condition for a pair of basketball shoe is. Three conditions were identified including 'comfort', 'fit', and 'feel' (NAK, 2002).

\section{Research Questions}

Prior to this study, there is no published data about the basketball shoe market in Hong Kong. Therefore, the efforts of the researcher are directed at investigating the basketball shoe brand preference of the young basketball enthusiasts by focusing on the following questions: What is the most preferred basketball shoe brand perceived by the young basketball enthusiasts in Hong Kong, China? What are the possible underlying factors of choosing the preferred band? Is there any gender difference when choosing the basketball shoe? What is the shopping behavior of the young basketball enthusiasts? Does NBA or athlete endorser have an effect on the youth's basketball shoe preference?

\section{Methodology}

In this study, young basketball enthusiasts were operationally defined as young people aged between 15 and 24 who reside in Hong Kong and play basketball regularly. In an attempt to investigate the research questions, a survey questionnaire was developed. The questionnaire was divided into three parts containing 18 multiple choice items. The first part contains items on demographic information and the behavioral patterns of playing basketball. The second part of the instrument measures the shopping behavior of the young basketball enthusiasts. How often do they purchase basketball shoes? Where do they buy the products? What are the reasons for choosing it? How much they are willing to pay? The final part contains items related to the basketball shoe brand preference and the impact of the NBA to the subjects.

A convenience-based random sample of the young basketball enthusiasts was used. The researcher collected the data from 12 different basketball courts according to the geographic region distribution in Hong Kong. A questionnaire was given to a basketball player. If a subject refused to respond to the survey, the random sequence of selection was followed to pick the next possible respondent. A total of 240, including 120 male and 120 female young basketball enthusiasts responded to the survey. Data were classified into two age groups and two gender groups for analytic purpose. The younger group ( $\left.\mathrm{n}=120 ; \mathrm{n}_{\text {male }}=60, \mathrm{n}_{\text {female }}=60\right)$ is of age 15 to 19 whereas the older group $\left(\mathrm{n}=120 ; \mathrm{n}_{\text {male }}=60, \mathrm{n}_{\text {female }}=60\right)$ age from 20 to 24. Based upon the population distribution characteristics of Hong Kong, stratified data were collected from three districts, namely Hong Kong Island, Kowloon, and the New Territories. Data were treated utilizing the Statistical Package for Social Science software. Descriptive statistics was utilized and data were presented in terms of percentages. Chi-square statistic was used to determine any gender difference in the selected items.

\section{Results}

The data were presented in terms of descriptive statistics for easier interpretation. 240 subjects responded to the survey. Data were collected from three districts in Hong Kong: Hong Kong Island (18\%), Kowloon (46\%), and the New Territories (36\%). Table I and II show the basketball playing habit of the subjects. Most of them played once to four times a week. They were very keen on playing basketball typically either for recreational purpose or team training for competition. The background of the subjects satisfied the operational definition of basketball enthusiasts as designed by the author and thus the data could be proceeded with further analysis. 
Table 1. Basketball Playing Habits of the Respondents.

\begin{tabular}{lll}
\hline Frequency & Play Outdoor & Play Indoor \\
\hline $1-2$ times/week & $63 \%$ & $78 \%$ \\
$3-4$ times/week & $28 \%$ & $17 \%$ \\
$5-6$ times/week & $7 \%$ & $2 \%$ \\
$>6$ times/week & $3 \%$ & $2 \%$ \\
\hline
\end{tabular}

Table 2. Reasons for Playing Basketball.

\begin{tabular}{llllll}
\hline Reasons for playing & Overall & $\begin{array}{l}\text { Male } \\
\text { age 15-19 }\end{array}$ & $\begin{array}{l}\text { Male } \\
\text { age 20-24 }\end{array}$ & $\begin{array}{l}\text { Female } \\
\text { age 15-19 }\end{array}$ & $\begin{array}{l}\text { Female } \\
\text { age 20-24 }\end{array}$ \\
\hline Team training & $53 \%$ & $52 \%$ & $35 \%$ & $60 \%$ & $65 \%$ \\
Recreational & $43 \%$ & $43 \%$ & $58 \%$ & $37 \%$ & $33 \%$ \\
Competition & $4 \%$ & $5 \%$ & $7 \%$ & $3 \%$ & $2 \%$ \\
\hline
\end{tabular}

\section{Shopping Behavior of the Young Basketball Enthusiasts}

Table 3 to 6 shows the shopping behaviors of the subjects. $60 \%$ of the respondents possess one to three pairs of basketball shoes. Interestingly, $24 \%$ of them have
4 to 6 pairs and even $11 \%$ possess 7 to 9 pairs. The age 20-24 group appears to have more basketball shoes as this represents that they have stronger consumption ability than their young counterparts. Surprisingly, regardless of age groups, $5 \%$ of the basketball enthusiasts possess more than 9 pairs of basketball shoes.

Table 3. How Many Pairs of Basketball Shoes Do You Have?

\begin{tabular}{llllll}
\hline & Overall & $\begin{array}{l}\text { Male } \\
\text { age 15-19 }\end{array}$ & $\begin{array}{l}\text { Male } \\
\text { age 20-24 }\end{array}$ & $\begin{array}{l}\text { Female } \\
\text { age 15-19 }\end{array}$ & $\begin{array}{l}\text { Female } \\
\text { age 20-24 }\end{array}$ \\
\hline $1-3$ pairs & $60 \%$ & $84 \%$ & $43 \%$ & $70 \%$ & $43 \%$ \\
$4-6$ pairs & $24 \%$ & $9 \%$ & $33 \%$ & $15 \%$ & $37 \%$ \\
$7-9$ pairs & $11 \%$ & $5 \%$ & $15 \%$ & $13 \%$ & $13 \%$ \\
$>9$ pairs & $5 \%$ & $2 \%$ & $9 \%$ & $2 \%$ & $7 \%$ \\
\hline
\end{tabular}

95\% of the respondents wear basketball shoes while playing or practicing basketball. In addition to the investigation of basketball shoe products, the present finding also revealed that sports market in basketball shorts and jerseys are a big business because about $90 \%$ of the subjects wear these sports products. Besides, there is a few subjects wearing wrist and head bands while playing basketball. About half of the respondents will purchase new basketball shoes within two to nine months. One-third of them intended to buy new basketball shoes in more than one year.

Table 4. What Kinds of Basketball Equipment Do You Wear/Use?

\begin{tabular}{llllll}
\hline & & Male & Male & Female & \multicolumn{2}{c}{ Female } \\
& Overall & age 15-19 & age 20-24 & $\begin{array}{l}\text { age 15-19 } \\
\text { age } 24\end{array}$ \\
\hline Basketball shoes & $95 \%$ & $95 \%$ & $92 \%$ & $93 \%$ & $100 \%$ \\
Basketball shorts & $90 \%$ & $90 \%$ & $80 \%$ & $95 \%$ & $97 \%$ \\
Basketball jersey & $82 \%$ & $77 \%$ & $75 \%$ & $88 \%$ & $88 \%$ \\
Bring your own basketball & $40 \%$ & $55 \%$ & $42 \%$ & $28 \%$ & $22 \%$ \\
Wrist bands & $15 \%$ & $13 \%$ & $10 \%$ & $23 \%$ & $15 \%$ \\
Ankle supporter & $13 \%$ & $13 \%$ & $8 \%$ & $15 \%$ & $17 \%$ \\
Head bands & $3 \%$ & $2 \%$ & $2 \%$ & $7 \%$ & $0 \%$ \\
\hline
\end{tabular}


Table 5. How Often Do You Buy a New Pair of Basketball Shoe?

\begin{tabular}{llllll}
\hline & & Male & Male & Female & Female \\
& Overall & age 15-19 & age 20-24 & age 15-19 & age 20-24 \\
\hline Within 1 month & $1 \%$ & $0 \%$ & $0 \%$ & $0 \%$ & $3 \%$ \\
$2-3$ months & $13 \%$ & $10 \%$ & $22 \%$ & $5 \%$ & $15 \%$ \\
$4-6$ months & $15 \%$ & $15 \%$ & $27 \%$ & $12 \%$ & $7 \%$ \\
$7-9$ months & $20 \%$ & $18 \%$ & $10 \%$ & $15 \%$ & $36 \%$ \\
10 months -1 year & $16 \%$ & $22 \%$ & $19 \%$ & $18 \%$ & $7 \%$ \\
$>1$ year & $35 \%$ & $35 \%$ & $22 \%$ & $50 \%$ & $32 \%$ \\
\hline
\end{tabular}

People in western countries usually buy things in nearby big shopping mall. In fact, Hong Kong people may have more varieties. Hong Kong is known as a shopping paradise. The street vendors carry many inexpensive items, such electronics, clothes and shoes. When asking the subjects where to buy their basketball shoes, interestingly, 59\% of them go to the 'Mongkok athletic shoe street' which is a popular shopping area located in the crowded city centre of the Kowloon district. The street contains about 50 athletic shoe stores within walking distance for shoppers. It is also a wellknown shopping street for most tourists.

Online shopping is the process consumers go through to purchase products or services over the internet. There is only $14 \%$ of the subjects utilizing internet to purchase their basketball shoes. It reflects that online shopping is not quite popular in Hong Kong perhaps due to the fact that Hong Kong is a small city and people can access to the place where they like to shop conveniently.

Table 6. Where Do You Buy Basketball Shoe?

\begin{tabular}{llllll}
\hline $\begin{array}{l}\text { Venue for shopping } \\
\text { basketball shoes: }\end{array}$ & Overall & $\begin{array}{l}\text { Male } \\
\text { age 15-19 }\end{array}$ & $\begin{array}{l}\text { Male } \\
\text { age 20-24 }\end{array}$ & $\begin{array}{l}\text { Female } \\
\text { age 15-19 }\end{array}$ & $\begin{array}{l}\text { Female } \\
\text { age 20-24 }\end{array}$ \\
\hline $\begin{array}{l}\text { Mongkok athletic shoe } \\
\text { street* }\end{array}$ & $59 \%$ & $41 \%$ & $68 \%$ & $65 \%$ & $62 \%$ \\
Sports chain store & $39 \%$ & $46 \%$ & $40 \%$ & $23 \%$ & $47 \%$ \\
Brand store & $15 \%$ & $26 \%$ & $13 \%$ & $13 \%$ & $7 \%$ \\
Internet & $14 \%$ & $2 \%$ & $13 \%$ & $14 \%$ & $28 \%$ \\
Shopping Mall & $10 \%$ & $14 \%$ & $12 \%$ & $2 \%$ & $12 \%$ \\
Department store & $5 \%$ & $2 \%$ & $2 \%$ & $12 \%$ & $6 \%$ \\
Nearby shops & $3 \%$ & $2 \%$ & $0 \%$ & $3 \%$ & $7 \%$ \\
Others & $5 \%$ & $5 \%$ & $2 \%$ & $2 \%$ & $9 \%$ \\
\hline
\end{tabular}

*Mongkok athletic shoe street is located in a densely populated shopping area in Kowloon, with about 50 athletic shoe shops. [respondents may choose no more than three choice items]

As shown in Table 7, $71 \%$ of the subjects chose to buy their basketball shoe because of the shoe 'style'. Perhaps this finding can be partly explained the reason why $24 \%$ and $11 \%$ of the young basketball enthusiasts possess 4 to 6 and 7 to 9 pairs, respectively. The basketball shoe manufacturers always launch new products with the latest style in order to attract their consumers. While looking into the gender under this factor, significant $(p$ $<.05$ ) gender difference exists. Over $80 \%$ of the female subjects ranked 'style' as the most crucial factor as a selection criterion to buy basketball shoe. Conversely, male subjects tend to be more concerned not only with the 'style', but also the 'price' and 'comfortableness'. These factors are in line with a similar survey conducted in
Japan (NAK, 2002). The 'price', 'comfortableness', 'function' are the subsequent influencing factors followed by the 'style'. Interestingly, only few subjects (10\%) indicated that the endorser's image factor play a significant role while choosing their basketball shoe. Perhaps the sport culture in Hong Kong is not as mature as that in mainland China cities. Unlike the successful sport market in the United States, the use of NBA stars as celebrity endorsers to promote basketball shoe products seems not as effective as the situation in the U.S. market. 
Table 7. What are the Most Influencing Factors for You to Buy a Pair of Basketball Shoe?

\begin{tabular}{llllll}
\hline $\begin{array}{l}\text { Most influencing factors } \\
\text { to buy: }\end{array}$ & Overall & $\begin{array}{l}\text { Male } \\
\text { age 15-19 }\end{array}$ & $\begin{array}{l}\text { Male } \\
\text { age 20-24 }\end{array}$ & $\begin{array}{l}\text { Female } \\
\text { age }\end{array}$ & $\begin{array}{l}\text { Female } \\
\text { age 20-24 }\end{array}$ \\
\hline Style & $71 \% *$ & $55 \%$ & $58 \%$ & $83 \%$ & $85 \%$ \\
Price & $64 \%$ & $50 \%$ & $65 \%$ & $68 \%$ & $73 \%$ \\
Comfortableness & $56 \%$ & $57 \%$ & $48 \%$ & $55 \%$ & $65 \%$ \\
Function & $45 \%$ & $43 \%$ & $30 \%$ & $55 \%$ & $50 \%$ \\
Famous brand & $27 \%$ & $27 \%$ & $33 \%$ & $23 \%$ & $25 \%$ \\
Endorsers' image & $10 \%$ & $12 \%$ & $13 \%$ & $7 \%$ & $7 \%$ \\
Collection value & $9 \%$ & $3 \%$ & $5 \%$ & $5 \%$ & $22 \%$ \\
\hline
\end{tabular}

*denotes significant gender difference exists at $\mathrm{p}<0.05$

[respondents may choose no more than three choice factors]

Table 8. What are the Basketball Shoe Qualities that Influence You to Buy?

\begin{tabular}{llllll}
\hline Shoe Qualities: & Overall & $\begin{array}{l}\text { Male } \\
\text { age 15-19 }\end{array}$ & $\begin{array}{l}\text { Male } \\
\text { age 20-24 }\end{array}$ & $\begin{array}{l}\text { Female } \\
\text { age 15-19 }\end{array}$ & $\begin{array}{l}\text { Female } \\
\text { age 20-24 }\end{array}$ \\
\hline Ankle protection & $71 \%^{*}$ & $63 \%$ & $60 \%$ & $82 \%$ & $77 \%$ \\
Light weight & $61 \%^{*}$ & $47 \%$ & $44 \%$ & $73 \%$ & $79 \%$ \\
Shock absorption & $45 \%$ & $55 \%$ & $55 \%$ & $34 \%$ & $40 \%$ \\
Durable & $29 \%^{*}$ & $47 \%$ & $35 \%$ & $19 \%$ & $14 \%$ \\
Traction & $27 \%$ & $30 \%$ & $29 \%$ & $22 \%$ & $25 \%$ \\
Breathable & $20 \%$ & $32 \%$ & $11 \%$ & $27 \%$ & $12 \%$ \\
Others & $3 \%$ & $2 \%$ & $4 \%$ & $3 \%$ & $2 \%$ \\
\hline
\end{tabular}

* denotes significant gender difference exists at $\mathrm{p}<0.05$

[respondents may choose no more than three choice factors]

Regarding the quality of basketball shoe as a selection criterion, female subjects tend to buy basketball shoes for reasons of better 'ankle protection' and 'light shoe weight'. In addition to 'ankle protection', male subjects prefer to have better 'shock absorption' as well. Playing basketball involves a lot of jumping and ankle/ foot injuries account for about $40 \%$ of basketball injuries (Borowski et al., 2008), and thus selecting a pair of good quality basketball shoe for injury prevention is the primary preference.
Table 9 shows how much the young basketball enthusiasts are willing to pay for purchasing a pair of basketball shoe. Majority of the subjects can afford to buy a pair of basketball shoe with money ranging from HK $\$ 301$ to $900.46 \%$ of the subjects would like to spend HK\$501 700 to buy one. These figures aid to provide information for the sports marketers to determine the retail price of basketball shoes in the Hong Kong market.

Table 9. How Much Do You Like to Pay to Buy a Pair of Basketball Shoe?

\begin{tabular}{llllll}
\hline & Overall & Male & Male & Female & Female \\
& & age 15-19 & age 20-24 & age 15-19 & age 20-24 \\
\hline$<\$ 300$ & $3 \%$ & $3 \%$ & $2 \%$ & $7 \%$ & $0 \%$ \\
$\$ 301-500$ & $23 \%$ & $22 \%$ & $17 \%$ & $45 \%$ & $7 \%$ \\
$\$ 501-700$ & $46 \%$ & $47 \%$ & $58 \%$ & $30 \%$ & $48 \%$ \\
$\$ 701-900$ & $19 \%$ & $23 \%$ & $19 \%$ & $12 \%$ & $23 \%$ \\
$\$ 901-1100$ & $7 \%$ & $5 \%$ & $2 \%$ & $5 \%$ & $17 \%$ \\
$>\$ 1101$ & $2 \%$ & $0 \%$ & $2 \%$ & $1 \%$ & $5 \%$ \\
\hline
\end{tabular}

1 US dollar $=\$ 7.8$ Hong Kong dollars 


\section{Basketball Shoe Brand Preference}

Each subject was asked to list out their current basketball shoe brands he/she possesses. A list summary across the age and gender was presented in terms of frequency counts, as shown in Table 10. Nike and Adidas are the top two brands preferred by most young basketball enthusiasts. Furthermore, when asking the subjects to list the basketball shoe brand that they recognize it as the best one, $82 \%$ of the respondents rated Nike as the best. Although Nike and Adidas are keen competitors in most sport markets, however, this finding comes into a view that Nike surpasses Adidas in the Hong Kong basketball shoe market.

Table 10. List the Basketball Shoe Brands You Currently Possess (in frequency counts)

\begin{tabular}{llllll}
\hline & Overall & Male & Male & Female & Female \\
& $\mathrm{N}=240$ & age $15-19$ & age 20-24 & age 15-19 & age 20-24 \\
\hline 1. Nike & 201 & 49 & 55 & 47 & 50 \\
2. Adidas & 100 & 30 & 23 & 16 & 31 \\
3. Air Jordan & 41 & 6 & 15 & 6 & 14 \\
4. Reebok & 22 & 3 & 11 & 5 & 3 \\
5. And 1 & 12 & 2 & 8 & 0 & 2 \\
\hline
\end{tabular}

Table 11. Which is Your BEST Basketball Shoe Brand Choose to Buy?

\begin{tabular}{llllll}
\hline & Overall & Male & Male & Female & Female \\
& $\mathrm{N}=240$ & age 15-19 & age 20-24 & age 15-19 & age 20-24 \\
\hline Nike & $82 \%$ & $68 \%$ & $91 \%$ & $78 \%$ & $92 \%$ \\
Adidas & $16 \%$ & $30 \%$ & $7 \%$ & $20 \%$ & $7 \%$ \\
And 1 & $1 \%$ & $0 \%$ & $2 \%$ & $0 \%$ & $1 \%$ \\
Others & $1 \%$ & $2 \%$ & $0 \%$ & $2 \%$ & $0 \%$ \\
\hline
\end{tabular}

\section{NBA Games and Athlete Endorsement}

The final research question is to determine if the NBA games and athlete endorsers have any effect on the basketball shoe brand preference of the young basketball enthusiasts in Hong Kong. Table 12 displays how often the local young basketball enthusiasts watch the NBA games. In fact, $31 \%$ of the subjects replied not watching NBA games. However, a further analysis on the gender factor revealed that significant difference $(\mathrm{p}<.05)$ was found in the watching frequencies between male and female subjects. About half of the female subjects show no interest in watching NBA games. Most of the male subjects responded that they watch the game frequently. Apparently, the use of NBA games as a basketball shoe promotional strategy seems not working well in the Hong Kong female groups.

Additionally, each subject was asked to indicate his/ her most favorite NBA player, as shown in Table 12. Many young Chinese basketball fans see Yao Ming as a national hero, but unexpectedly, Yao is not ranked with the top five most favorite players by the male subjects. Yao Ming is only liked by the female subjects.

\section{Table 12. How Often Do You Watch NBA Every Week?}

\begin{tabular}{llllll}
\hline & & Male & Male & Female & Female \\
& Overall & age 15-19 & age 20-24 & age 15-19 & age 20-24 \\
\hline $1-2$ times & $49 \%$ & $49 \%$ & $67 \%$ & $39 \%$ & $40 \%$ \\
$3-4$ times & $13 \%$ & $25 \%$ & $14 \%$ & $5 \%$ & $7 \%$ \\
$5-6$ times & $3 \%$ & $5 \%$ & $4 \%$ & $0 \%$ & $2 \%$ \\
$>6$ times & $4 \%$ & $11 \%$ & $5 \%$ & $2 \%$ & $0 \%$ \\
Do not watch* & $31 \%$ & $10 \%$ & $10 \%$ & $54 \%$ & $51 \%$ \\
\hline
\end{tabular}

* denotes significant gender difference exists at $\mathrm{p}<0.05$ 
Table 13. Most Favourite NBA Players Perceived by the Subjects.

\begin{tabular}{lllllll}
\hline $\begin{array}{l}\text { Favourite } \\
\text { NBA players }\end{array}$ & Male & $\begin{array}{l}\text { Endorsed } \\
\text { basketball } \\
\text { shoe brand }\end{array}$ & $\begin{array}{l}\text { Position } \\
\text { played }\end{array}$ & Female & $\begin{array}{l}\text { Endorsed } \\
\text { basketball } \\
\text { shoe brand }\end{array}$ & $\begin{array}{l}\text { Position } \\
\text { played }\end{array}$ \\
\hline 1st & Kobe Bryant & Nike & guard & Kobe Bryant & Nike & guard \\
2nd & Michael Jordan & Nike & guard & Michael Jordan & Nike & guard \\
3rd & Lebron James & Nike & forward & Yao Ming & Reebok & center \\
4th & Chris Paul & Nike & guard & Kevin Garnett & Adidas & forward \\
5th & Steve Nash & Nike & guard & Lebron James & Nike & guard \\
\hline
\end{tabular}

\section{Table 14. Do You Pay Attention to the Following Basketball News?}

\begin{tabular}{lll}
\hline Events: & Yes & No \\
\hline NBA & $75 \%$ & $25 \%$ \\
Basketball Products & $62 \%$ & $38 \%$ \\
Local Basketball News & $62 \%$ & $38 \%$ \\
International basketball News & $54 \%$ & $46 \%$ \\
\hline
\end{tabular}

Table 15. Where Do You Obtain Basketball Information?

\begin{tabular}{ll}
\hline Sources: & Percentage \\
\hline Newspaper & $64 \%$ \\
TV & $59 \%$ \\
Internet & $51 \%$ \\
Magazine & $25 \%$ \\
Others & $3 \%$ \\
\hline
\end{tabular}

Most of the subjects obtain basketball information from three sources: newspaper, TV, and internet. From the present data, it appears that the NBA games do not contribute too much effect on basketball shoe advertising message to the Hong Kong young basketball enthusiasts

\section{Discussion}

The results of the survey attempted to empirically understand the basketball shoe brand preference of the young basketball enthusiasts in Hong Kong. It was found that the most primary concerns for the Hong Kong young basketball enthusiasts to buy their basketball shoes are 'shoe style' and 'price' factors. Interestingly, more than $80 \%$ of female subjects in this study buy their basketball shoes because of the way they look and feel (style). The product design of sporting goods influences consumer perceptions of product quality, such as color and styles (Shank, 2009). Females always have a preference on fashionable items and many sport marketers recognize women and girls are a special group of consumers with special needs and wants (Mullin et al, 2007).
In this study, the 'endorser image' factor received relative lower ranking as perceived by the subjects. Unlike the Taiwan sport market case in which athletes' exposure can enhance Taiwan consumers' perception on the endorsers as well as consumers' intention to purchase the endorsed product (Jen-Mo, 2005). This may be due to only $69 \%$ of the Hong Kong subjects responded to watch NBA games. Therefore, the NBA stars as basketball shoe endorsers, were not recognized as an important influencing factor.

Nike was found to be the best basketball shoe brand recognized by the subjects. Nike's Air Jordan basketball shoes are considered for the performance characteristics and a firm connection with a popular U.S. sport, and the endorsement from the pre-eminent star of that sport: Michael Jordan (Porter et al, 2002). Although Michael Jordan retired for long time, he was still the second most favorite player ranked by today's young basketball fans in Hong Kong. From this survey, Air Jordan basketball shoe brand even now received the third rank, following Nike and Adidas. Michael Jordan as a sport star has contributed a lot to the sport market and business sector. Perhaps the relationship between Nike and Michael Jordan may be interpreted in terms of brands and branding concept as illustrated by Mullin et al (2007). 
The top five most favorite NBA players recognized by male respondents all wear Nike basketball shoes. On the contrary, the top five most favorite players chosen by female subjects wear various basketball shoe brands, including Nike, Reebok, and Adidas. For male subject group, they may consider their basketball shoe brand as a social identify (Ohl and Taks, 2007). Buying a pair of Nike basketball shoe can imply a variety of things, such as being recognized by other pupils at school, looking older or younger, looking like a hero, being a fan, and being a member of a club. As a result, purchasing specific sporting goods is associated with social experiences and networks, and therefore contributes to the construction of social identity. On the other hand, the social networking in the female group is not as solid as the male basketball players in this study.

Further investigation may be conducted in exploring the brand loyalty among the young basketball enthusiasts in Hong Kong. Loyal consumers represent repeat customers, which can lead to cost savings for brands as spending resources on attracting news customers becomes less essential (Rentshler et al., 2002). Although brand loyalty has been researched in sport setting, the topic of brand trust has not been thoroughly examined (Filo et al., 2008).

Sport is an economically significant, highly popular, globally networked cultural form. Global sport is now a serious and increasingly financially rewarding business. Sport event, like NBA games, through global broadcasting, sponsorship and endorsement arrangements offer commercial corporations unique access to global consumer culture (Smart, 2007). Due to very limited published data available concerning the basketball shoe market in Hong Kong, the finding of this study is able to provide global basketball shoe marketers with a database about the situation in Hong Kong. As global sport markets expand drastically, future research on investigating basketball shoe market should be conducted in the fast-growing Oriental sport market.

\section{References}

Archenreiner, G. B., \& John, D. R. (2003). The meaning of brand names to children: a developmental investigation, Journal of consumer psychology, 13 (3), 205-219.

Bailey, A. A. (2007). Public information and consumer skepticism effects on celebrity endorsements: Studies among young consumers, Journal of marketing communications, 13 (2), 85-107.

Borowski, L. A., Yard, E. E., Fields, S. K., \& Comstock, R. D. (2008). The epidemiology of US high school basketball injuries, 2005-2007, American Journal of Sports Medicine, 36 (12), 2328-2335.

Carlson, B. D., \& Donavan, D. T. (2008). Concerning the effect of athlete endorsements on brand and teamrelated intentions, Sport marketing quarterly, 17 (3), 154-162.

Filo, K, Funk, D. C., \& Alexandris, K. (2008). Exploring the role of brand trust in the relationship between brand associations and brand loyalty in sport and fitness, International journal of sport management and marketing, 3 (1.2), 39-57.

Fullerton, S. (2007). Sports marketing. New York: McGraw-Hill.

Fullerton, S., \& Merz, G. R. (2008). The four domains of sports marketing: A conceptual framework, Sport marketing quarterly, 17, 90-108.

Hong Kong Sports Development Board (2001). Sports participation survey, research report. Hong Kong Sports Institute.

Hong Kong Sports Development Board (2002). Economic impact of sport, research report. Hong Kong Sports Institute.

Hong Kong: the fact (2008). Coming to Hong Kong. November, p. 2. 
Jen-Mo, G. (2006). The effectiveness of sports' brand endorser's credibility on consumers' buying decision: Nike and adidas basketball endorsers for research purpose. Master's thesis, Nation Sun Yat-sen University, Taiwan.

Jones, M., \& Schumann, D. (2002). The strategic use of celebrity athlete endorsers in sports illustrated: A historical perspective. Sport marketing quarterly, 9 (2), 65-76.

Kohli, C., Harich, K. R., \& Leuthesser, L. (2005). Creating brand identify: a study of evaluation of new brand names. Journal of business research, 58, 1506-1515.

Kohli, C., Leuthesser, L., \& Suri, R. (2007). Got slogan? Guidelines for creating effective slogans. Business horizons, 50, 415-422.

Louie, L. (2001). A Study between Sport Participation and Individual Health Care Expenditure on Hong Kong Adults, research report no. 5. Hong Kong Sports Institute.

Louie, T. A., \& Obemiller, C. (2002). Consumer response to a firm's endorser (dis)association decisions. Journal of advertising, 31 (4), 41-52.

Mullin, B. J., Hardy, S., \& Sutton, W. A. (2007). Sport marketing $\left(3^{r d} e d.\right)$. Campaign, IL: Human Kinetics.

NAH, K. (2002). The conditions for a 'good' athletic shoe: a questionnaire survey of basketball shoes, available at http://sciencelinks.jp/j-east/journal/J/ S0258A/2002.php (accessed 28 December 2008)

Ohl, F., \& Taks, M. (2007). Secondary socialization and the consumption of sporting goods: cross cultural dimension. International journal of sport management and marketing, 2(1/2), 160-174.

Porter, J., Harris, M., \& Yeung, G. (2002). "Nike", Management 296: International business management, 11 December.
Rentshler, R., Radbourne, J., Carr, R., \& Rickard, J. (2002). Relationship marketing, audience retention and performing arts organization viability. International journal of nonprofit and voluntary sector marketing, 7 (2), 118-130.

Shank, M. D. (2009), Sports marketing: a strategic perspective, Upper Saddle River, NJ: Pearson.

Smart, B. (2007). Not playing around: global capitalism, modern sport and consumer culture. Global network, 7 (2), 113-134.

Todd, E.L. (2006). Spotlight on international sports marketing. Albuquerque Journal, 26 November, D2.

\section{Correspondence:}

Dr. Lobo Louie

Department of Physical Education,

Hong Kong Baptist University, Kowloon Tong,

Hong Kong.

Email: s62591@hkbu.edu.hk 